\title{
Challenges Faced by Novice English Language Instructors in the application of their Teaching Strategies: A Case Study of University A
}

Jondy M. Arpilleda, Ph.D.

College of Arts and Sciences, Surigao del Sur State University, Philippines

Received: 07 Sep 2021; Received in revised form: 02 Oct 2021; Accepted: 09 Oct 2021; Available online: 15 Oct 2021 (c)2021 The Author(s). Published by Infogain Publication. This is an open access article under the CC BY license (https://creativecommons.org/licenses/by/4.0/).

\begin{abstract}
This qualitative research study used the semi-structured interviews and classroom observations in exploring the challenges faced by novice English language instructors in University A. These qualitative methods have provided the author the means of capturing the participants' experiences and actual teaching performance. Participants were chosen from among five newly employed English instructors. The findings revealed that majority of the participants used constructivist, communicative language teaching, and performance-based strategies in their classes. This can be explained by their educational background, as the majority of them have a master's degree. This is also attributed to their previous teaching experience and the pedagogical seminars and training they have attended. Four primary challenges surfaced as having an effect on the participants' efficiency to teach. These factors include leaners' individual differences, availability of instructional materials, class size, and various school activities, which disrupt classes. More specifically, the participants disclosed that the learners' attitudes toward the subject and their studies interests and capacity to learn greatly affect their instructional strategy. They also revealed that having big class size (40 or more students) is not desirable for language courses.
\end{abstract}

Keywords-Challenges, Novice Teachers, Teaching Strategies.

\section{INTRODUCTION}

The European Commission (EC) recognized the need to support beginning teachers' lifetime learning, but argued that schools should not be completely responsible for their educators' effectiveness. Teachers should participate in the process as well, because the expectations of the teaching profession are changing rapidly, and they must fulfill these demands. Teachers face new challenges in terms of effectiveness in the classroom and the ability to adapt to students' changing needs in a world of rapid social, cultural, economic, and technological change (European Commission. (2009).

However, several studies have offered fascinating insights into the areas where novice teachers frequently struggle. Schools can help new teachers enhance their skills, keeping them in the field and boosting student achievement, by properly addressing these areas. The study of Rivkin, Hanushek and Kain (2005) specifically disclosed that students' achievement is significantly worse in the classrooms of beginning teachers. This steep learning curve is difficult not only for the students, but also for the teachers. As a result of feeling overwhelmed, ineffective, and unsupported, $15 \%$ of beginning teachers leave the profession, while another $14 \%$ change schools after their first year (Ingersoll \& Smith, 2003; Smith \& Ingersoll, 2004).

Similarly, Goodwill (2012) identified three major problems faced by beginning teachers: (1) the classroom management; (2) curriculum; and, (3) unsupportive environments.In his study of 500 teachers, he discovered that new teachers, those with less than three years of experience, were more likely to declare that student 
behavior was a problem in their classes than those with more experience. Hover and Yeager (2004) also found out that new teachers may abandon many of the researchbased instructional approaches they studied in college (such as cooperative learning and project-based learning) in favor of a continuous use of lectures and textbooks due to classroom management issues.

Another concern that new teachers commonly raise is a lack of guidance and resources for lesson and unit planning. According to a recent study of over 8,000 American teachers, $41 \%$ stated their schools or districts provided them with minimal or no instructional tools including lesson plans and textbooks. When classroom materials were given, they were rarely beneficial; only $15 \%$ of respondent-teachers said the materials were of good enough quality to utilize freely (Mathews, 2011). Furthermore, some case studies have revealed that new teachers spend 10 to 12 hours a day multitasking lesson planning, grading, and attending to myriad demands of paperwork, committees, and extracurricular assignments. Another issue is the "sink-or-swim" quality of many first-year teacher experiences, which is widely cited as a major challenge. New teachers frequently report challenging encounters with colleagues, ranging from administrators' "benign negligence" (Fry, 2007) to senior teachers' lack of cooperation or even animosity.

With the above-mentioned information, the researcher was prompted to venture on this study to discover the challenges met by newly-hired English instructors in University A, especially in the application of their teaching strategies. This study also sought to discover whether the newly-hired university English instructors experience the same problems and challenges like those secondary and elementary teachers. Specifically, this endeavored to answer the following questions: (1) what are the teaching strategies commonly used by the novice English instructors; and, (2) what are the challenges they faced in the application of their teaching strategies?

\section{REVIEW OF RELATED LITERATURE}

This study is anchored on Vygotsky's (1978) Sociocultural Theory, which provides a lens for examining how the newly hired teachers become expert in their profession, and how they learn to appropriately teach students. The theory serves as a means of understanding and examining how they go through their teaching tasks, what are the problems they met in the application of the teaching strategies and how these problems affect their effectiveness as teachers. Such lens allows us to understand the teachers' beliefs and environment which play a significant role in practicing their profession. These influential factors and challenges, learning and support are viewed with a sociocultural lens (Putnam \&Borko, 2000).

Beginning teachers, according to Onafowona (2004), should be viewed as empowered persons who should look to themselves for continuing progress in their effectiveness within a nurturing culture. This is because learning from practice must take place within supportive professional learning communities if beginning teachers are to align their practices with a student-centered model of teaching and teach from a place of authenticity (Sewell, 2011).

However, the European Education (2009) emphasizes that at minimum, beginning teachers should possess specialist knowledge of the area they teach, in addition to the required pedagogical skills. Furthermore, these teachers should be able to teach heterogeneous classes, make efficient use of information and communication technology (ICT), and help learners to acquire transferable competencies. Such endeavors are facilitated by a backdrop of key professional values namely: autonomous learning; reflective practice; participation in research and innovation; collaboration with colleagues and parents; and an engagement in the progress of the whole school.

Flores and Day (2006) discovered that more often than not, some schools that hire teachers have erroneous beliefs that beginning teachers have already acquired all that is required to successfully carry out their responsibilities in their context. Thus, any shortcomings in terms of classroom delivery are seen as their fault. This situation is worse for beginning teachers who fail to seek the necessary support from experienced teachers and school leaders, mainly because such a move might be seen as a sign of weakness.

Mc Cormack, Gore, \& Thomas (2006) discovered that novice teachers often appear to yearn for, yet seldom receive, meaningful feedback on their teaching from experienced colleagues and administrators. Regrettably, teacher mentors, ostensibly assigned to provide this support, were sometimes part of the problem, dispensing little guidance, if not bad advice (Fry, 2007). In other situations, some of the range dilemmas that novice teachers encounter is in areas such as curriculum, lesson planning, assessment, management, time and school culture (Feimen-Nemser, 2003).Lesson preparation, inability to identify pedagogical implications for each student, and knowledge of subject matter are among the other issues identified (Reynold, cited by Bozack, 2008).

Furthermore, Windschitl, et al. (2010) observed the same issues among their previous graduates who work in secondary schools. They discovered that: (1) many 
beginning teachers could not identify substantive relationships between concepts in the form of scientific models that help learners understand, explain, and predict a variety of important phenomena in the natural world; (2) beginning teachers could only initiate a conversation in the classroom, but appears to lack the skills to sustain a science discourse in the classroom; and (3) the beginning teachers chose broad themes such as "student ownership," "critical thinking," and "relevance" for planning their lessons. This made conceptualization difficult and, as a result, ineffective.

Moreover, Veeman, cited by Bozack (2008) state eight problems often encountered by newly qualified teachers as (a) discipline, (b) motivating students, (c) how to deal with individual differences, (d) assessment of students' work, (e) relationships with parents, (f) class work organizations, (g) inadequate teaching materials, and (h) dealing with the problems of individual students. $\mathrm{He}$ and Cooper (2011) on their study entitled Struggles and strategies in teaching: Voices of five novice teacher secondary teachers found out that their participants experienced (a) lack of administrative support, (b) testing pressure, (c) lack of up-to-date resources, (d) lack of parental involvement, and (e) the difficulty of balancing their teaching responsibilities and their personal lives. Some beginning teachers faced challenges like they are prevented from implementing many innovative classroom practices and they are isolated (Mckenzie, 2005).

\section{METHODOLOGY}

\section{Research Design}

The methods namely semi-structured interviews and observations were used in this study. These qualitative methods allow for the recording of participants' experiences as well as accurate descriptions of those experiences. It is possible to grasp the circumstances, processes, and meanings that are important to the investigated participants by using an ethnographic framework that allows for observation, casual talks, and semi-structured interviews (Whitehead, 2005). The data collected in the study were mostly taken from the interviews with the five (5) newly hired English instructors of University A. The researcher also assumed that there was a need to gauge the unpacking of these teachers' teaching strategies within the classroom context; therefore, five (5) classroom unstructured observations using field notes were conducted.

On the other hand, the semi-structured interviews were also conducted by the researcher which aimed at ascertaining the meaning of effective teaching practices from these teacher participants and the challenges they met in the implementation of such instructional strategies. The interviews with the newly hired teachers focused on these areas: (1) their educational attainment, seminars and training they have attended and the teaching strategies they use; and, (2) the challenges they face in the application of these teaching strategies. Moreover, aside from class observations, the researcher made follow-up semistructured interviews to allow the capturing of the each of the participants' philosophies and reasoning in using specific teaching approaches.

The inductive analysis approach was used for analyzing the emerging qualitative data of the study undertaken. Patton (2002) described inductive analysis as, "immersion in the details and specifics of the data to discover important patterns, themes, and interrelationships; begins by exploring, then confirming; guided by analytical principles rather than rules and, ends with a creative synthesis". As a result, rather than assuming what these dimensions will be, an inductive method aims to allow relevant patterns discovered from the situations under investigation to emerge from the data. In order to better understand the influences on teachers' classroom practice and how these issues affect the implementation of effective teaching practices, the researcher concluded that an inductive analytic technique was effective in obtaining data from and across cases.

\section{Participants}

The five participants were purposely chosen based on the following criteria: (1) they are just newlyhired English instructors of the institution; (2) they represent the five colleges of the university; (3) their work experience is not more than five years; and, (4) they willingly volunteered their time for the study. The information below are the characteristics of each of the participants whose age range is from 23 to 27 years old.

Teacher A's highest academic qualification is a master's degree holder major in English Language Teaching. With regard to her teaching experience, she worked for 3 years at university $A$ as a contractual employee in the College of Engineering, Computer Science and Technology. She was given the permanent status after she finished her master's degree.

Teacher B's highest academic qualification is a master's degree holder major in English Language Teaching also. As to her teaching experience, she had taught 4 years at university $\mathrm{A}$ as a contractual employee in the College of Arts and Sciences. But before she was hired by university $\mathrm{A}$, she worked before at a university in Butuan city for a year. She was given the permanent status after she graduated her master's degree. 
Teacher C's highest academic qualification is a Bachelor of Arts degree holder major in Communication Arts. She is currently pursuing her master's degree in English Language. With regard to her teaching experience, she has taught 2 years at university as a contractual employee in the College of Business and Management.

Teacher D's highest academic qualification is a master's degree in education. With regard to his teaching experience, he had taught 2 and half years at university as a contractual employee in the College of Teacher Education. He was given the permanent status after he earned his master's degree.

Teacher E's highest academic qualification is a master's degree holder major in English and Literature. She worked as a contractual employee at the College of the Graduate School for 3 years. She is currently connected with the Department of Education as education program specialist.

\section{Data Collection}

In this study, the researcher used two data collection methods to allow for the triangulation of data. The methods were interviews and classroom observation. The researcher developed a semi-structured interview guide which ultimately generated data on the commonly used teaching strategies of the English instructors and the challenges they faced in the application of these teaching strategies. The semi-structured interview was conducted for an average duration of 30 to 40minutes, which took place during the teachers' break time. All the interviews were tape recorded.

On the other hand, the class observation to each of the participants was done unannounced to check whether the participants were really applying the teaching strategies that they have mentioned during the interview. Each observation lasted for 30-40 minutes in the sense that it not only contained the teaching and learning methods intended to be observed but also made provision for the collection of other data that illuminated the teaching/activities of these English teachers.

\section{RESULTS AND DISCUSSIONS}

This section presents and describes the thematized teaching strategies that the teacher participants commonly use in their classes based on the interviews and classroom observations. This also reports the challenges these English instructors experienced, which they believe have affected their teaching strategies.

What Teaching Strategies Do the Beginning Teachers Commonly Use?
Four of the participants (Teachers' A, B, C, and E) predominantly use constructivism, performance-based teaching strategies and outcomes-based assessment techniques in their classes and only one, Instructor D tends to subscribe the traditional way of teaching--- the lecture method.

Constructivism, Performance-based, Communicative Language Teaching and Outcomes-based Education. Teachers A, B, C and E revealed that they learned these teaching strategies mostly from their undergraduate and graduate studies and from various seminars and training that they have attended.

Teacher A said:

When we were hired as contractual employees three years ago, we had undergone training on outcomesbased education for one week. One of the topics of that training was on the design of teaching strategies and assessment techniques. I really learned a lot from it, Sir. It was also emphasized by our subject area coordinator that this is what we must do in our classes because it is mandatory and it should be reflected in our syllabus. So, that is what I apply in my classes, the outcomesbased assessment strategies.

For Teacher B, aside from outcomes-based assessments, she also applies communicative language strategies and constructivism approach. She said:

In my part Sir, I usually apply communicative language teaching because I found this very effective especially in my English 102 (writing in the discipline) and English 3 (speech and oral communication) classes. The students enjoyed my class because of the various strategies that I use and most importantly they are learning. Then, all of my assessment strategies are performance-based especially in my English 3 classes; I let my students perform oratory, different types of speeches, speech drills, drama, and many more. I believe Sir that these strategies were effective because according to an author, (pause) I just forgot his name, that if we want to let students learn how to talk, then we 
have to let them talk, and that is what

I am doing.

Teacher B also added that she learned these strategies from her former colleagues because it was a practice in her former workplace to have re-echoing if someone is being sent to a training or workshop. She said that they also have team-teaching, so it was a great help for her especially during her first semester stay at the university.

On the other hand, Teacher $\mathrm{C}$ divulged that she usually uses outcomes-based assessment techniques she learned from her graduate studies and from the training conducted by the university. She added:

I usually use outcomes-based assessment techniques Sir because it effective. Then, this is also being required in our syllabus (chuckles). Joking aside, in my case Sir that I handle research subject and English 106 (Business Correspondence and Technical Writing), I usually require students to make outputs like formal letters, feasibility studies, proposal and research papers. So far, though it is both heavy for me and students, it's really worthy because they have learned.

Teacher E specifically said:

In my case, Sir I learned these teaching techniques from my own readings because my graduate thesis was about communicative language teaching. So, I am well aware of the effective strategies to use on how to develop the communication skills of the students."

During the interview, the common teaching strategies that came out to be regularly used include role playing, discussions and conversations, oral presentations, games, group reporting, writing essays, research papers, reflection papers, film reviews and literary critiques and individual reporting. However, Teacher D divulged that he sometimes uses lecture method or individual reporting because he wanted that students will learn from his discussion. He added:

I am the teacher, so I am expected to be knowledgeable about the subject matter. If I am going to let students do the reporting especially on difficult topics, what would they share? But I also assign students to do individual reporting because I want to develop their sense of responsibility, resourcefulness and industry. I am doing it Sir because they are future teachers and I want them to learn how to effectively report. Aside from that reporting develop the students' confidence and communication skills. I don't like outcomes-based strategies because they are time-consuming and very laborious on my part because I handle 9 subjects and I have a big class size.

These claims were validated by the researcher's informal observations with them. One time, when he made class observation to Teacher $\mathrm{B}$ and $\mathrm{C}$, the former was already collecting the group outputs of her students. From the looks it, he assumed that Teacher B had given a reading task as shown by the handouts in each group. After she was informed by the class observation, Teacher B continued the activity by requesting each leader of the group to present the group output. She asked from time to time the leader probing questions and encouraged the other group to participate. On the other hand, Teacher $\mathrm{C}$ during the observation in her literature class, she grouped her students into 5 with 6-7 members and then used the jigsaw strategy in exploring the five elements of plot conflict. The class was a bit noisy with everyone participating in the group activity. With all the class observations, the researcher found out that these beginning teachers are actually using the teaching strategies that they have mentioned: performance-based assessment tasks, constructivist approaches, outcomes-based assessments and communicative language teaching strategies. Only teacher D used the demo-teaching method, which the researcher is also a performance-based assessment.

What are the Challenges Faced by the Novice English Instructors in the Application of the Teaching Strategies?

It is a no brainer to immediately conclude that newly hired teachers' first year on a job is often difficult. They will face certain challenges, and experience culture shock in carrying out their works unless they are well aware beforehand of the ins and outs of the institution. In the interviews with the participants, four major problems emerged to be very prevalent. These include: attitudes of students, instructional materials, class size, and unanticipated school activities.

Attitudes of Students. Teachers B and D specifically revealed that last year, during the first semester, they have 
had hard time adjusting to the types of students they have in each class. It took time for them to fully assess the students' level of learning and interests.

Teacher B recounted:

In one of my English 2 (Writing in the discipline) classes composed mostly of Bachelor of Arts in Political Science I encountered a sort of discrimination. I sensed it by the way they looked at me and how they behaved. I surmised they instantly assumed that I am inexperienced. So, what I did was to come to class prepared every meeting and gave them challenging and mind-boggling activities. Gradually I gained their respect.

On the other hand, Teacher $\mathrm{D}$ revealed that he was having difficulty adjusting to the attitudes of his students at first. He lamented:

When I assigned for individual reporting, the first group of reporters were not able to deliver what I expected from them. I was really disappointed at that time that I had reproached them. I explained to them why I was doing it, it was somewhat a dialogue... and after I aired my side, I challenged them to give their best in the assigned report next time. The good thing after that incident, my students were already accustomed to my way of teaching and gave their best.

Teacher $\mathrm{C}$ was the only one who complained about the indiscipline of her students. Her students were unpunctual and noisy. Students' undiscipline is one of the problems that is faced by novice teachers (Watson, 2006). Teacher C said:

You Sir, they are graduating students, so they feel as though they are already untouchables because they must graduate. What I did, I really showed to them that I am unfazed to fail them. You were afraid; hence they come to my class and avoid being late.

Availability of Instructional Materials. In terms of instructional materials, Teachers A, B, and C disclosed that textbooks and modules are wanting in their classes. They said that they mostly rely on the limited textbooks they borrowed from the library and the information they got from the internet. In sharing their resourcefulness, Teachers A said:

What I usually do is to assign my students to research for the topic in the internet. Then, I gave them points if they can provide printed copies of the researched topic. Sometimes I also post the topics in our facebook group and gave assignments there. So, they will just search for some information available on the net.

Meanwhile, Teachers B and Clet their students photocopy the handouts they have prepared ahead of time and have these photocopied by their students.

Teacher B added:

I give extra points for students who can bring the printed copy in my class, this is my way of compelling them to provide a copy for themselves. If I have no handouts, I will assign my students to provide a copy of one chapter of the book and have it prepared in our class for discussion.

On the other hand, Teacher C usually compelled each student to buy the book that they are using. She recounted:

Ahmm, I usually let buy a book, Sir.

Sometimes I have it by pair, sometimes I let them buy individually. It's a bit tough if I always let them photocopy some portion of the book because oftentimes, they come to class late, and others don't have a copy. So, I really encourage them to by a book because it will serve as their project in the prelims. Good thing, they will also buy (chuckles).

Large Class Size. Another problem that the teacher participants experienced is the large class size. Four of them Teachers A, B, C and D revealed that the number of students they handle in each class is not ideal; especially that it means a huge work for them.

Teacher A specifically decried over the bulk of assignments she is going to meticulously check for her English 2 classes and the limited time she could squeeze just to make sure these outputs returned on time. 
It's really tough on my part, Sir. Sometimes I bring home the students' requirements and I do the checking there because my eight hours stay in school is not enough to finish them Very stressful. Instead of taking a break on weekends, sometimes I have to do some paper works just to finish assessing my students' outputs

Teacher $\mathrm{B}$ and $\mathrm{C}$ also shared their problems on carrying out a performance-based assessment on their English classes. Teacher $\mathrm{C}$ specifically revealed:

Take for example Sir, I will let students perform a debate or individual oral presentations like oratory and story-telling. These activities or tasks take time so much time because I have more than 40 students. Sometimes it took me 2 to 3 days before everyone in my class is done with his/her presentation. This actually drags my lessons, but I have no choice, otherwise students won't learn how to communicate in English fluently, which is of course, the main purpose of the subject.

In addition, Teacher $\mathrm{D}$ suffered the same problem. He lamented:

Having 40 students is really tough especially if you handle education students. For example, I assign each student a demo-teaching, this will consume one period of our class so more this drags our lesson. That is why we should hold make -up class to compensate the missed lessons that we have to cover, Sir.

School Activities. Moreover, all the participants divulged that school activities like ocular visits of CHED, intramurals, seminars and training, accreditations, local holidays, University Day, Family Day, etc.) and many more greatly affect their teaching strategies. When asked why, Teacher A specifically said:

AACCUP Accreditation for instance is really a big burden to us. It is because we are compelled to do extension services even during school days just to comply the necessary documents demanded by their evaluation instrument. Then, the most tiresome part is the week before the accreditation that we more often than not we sacrifice our classes and class preparations just to comply all the necessary documents.

In addition, Teacher B disclosed that Intramurals, College Week, tactical inspection and other school activities disturb her classes. The loud speaker from the announcer, the students' boisterous yells and sounds of drum and bugle corps cause much annoyance. She added:

\begin{abstract}
My students have hard time concentrating in the class activities because their attention is being diverted from the noise outside or from the activities being done. They also cause some delay on the pace of our lessons; so, my schedule is messed up. Sometimes, there are some unexpected school activities. Teachers and students are being pulled from their classes to attend or participate in those events.
\end{abstract}

On the other hand, Teacher D lamented:

One thing also Sir that I dislike is the Sportsfest or Intramurals because this really disrupts my classes. Some of my students are busy practicing especially those who are players or contestant of a certain literary contest or socio-cultural competition. Even a month before the intramurals, students are already busy and others cannot anymore attend classes.

\section{CONCLUSIONS AND RECOMMENDATIONS}

Based on the participants' interview (FGD), majority of the participants used performance-based, constructivists and outcomes-based strategies in their classes. These strategies are learner-centered, meaningful, collaborative, interesting and engaging, output-oriented and based on real life situations. This is the case because almost all of them are master's degree holders, meaning they have been exposed to various theories and teaching strategies during the course of their studies, and more importantly this is attributed to their past teaching experience. One of them comes from other universities not from Tandag city and four worked at University $U$ as 
contractual employee before they were hired as regular or permanent employees.

Only one, Teacher D subscribes to the lecture and reporting or the banking method or the traditional style of teaching. Yet, even so, teacher D has a point when he reasoned out that he used them because his students might go into teaching and some might soon be speakers in conferences so they should be trained to gain confidence to face the crowd alone. His reason proves the fact that some well-experienced and educated teachers still cling to traditional methods because they stick to their own beliefs based on what is most effective to a certain subject and to a certain group of learners. Also, this instance suggests that teachers should not immediately throw the old strategies and thoughtlessly embrace the new one. Besides, in any educative process, students should really be the focal point of everything.

On the other hand, the four major problems, which were predominant mentioned by the participants include: the attitudes of students, availability of instructional materials, large class size, and school activities. It is indeed true that the type of learners and their attitudes greatly affect the teachers' mood and even her/his teaching strategies because there are instances that students become uncontrollable and indifferent. There are students that are slow and fast learners; some have attitudinal problems like laziness and passivity; and, others have various interests. So, this heterogeneity ultimately affects the teachers' lesson planning, especially in identifying what instructional strategy to use. Thus, it is imperative for teachers to assess first the weaknesses and strengths and needs of their students before they decide on what teaching techniques or strategies to use. However, it is worth mentioning that these novice teachers are resilient and strong to ingeniously confront the attitudinal problems of students and gain their respect.

Instructional materials like modules and textbooks, as revealed by participants, are lacking too. Teaching modules or students' modules ease the work of teachers because they provide many activities and lessons ready for use. Hence, they should be available in the campus, if not, textbooks could suffice. Moreover, majority of the participants also complained about their large class size. They disclosed that they have 40-50 students in a class; sometimes they have more than 50 students. This class size is not ideal for teaching English subjects, specifically in speech and writing subjects and in using performance-based assessments. Checking of the students' paper one by one takes time; same is true in evaluating their individual performance. Moreover, school activities and programs, especially the unanticipated, affect teachers' performance in class. Time element is very essential in outcomes-based and performance-based assessment, if teachers are squeezed with their time, they would lose momentum and oftentimes they find difficulties applying these teaching strategies. Noise too causes distraction to students' attention and teachers' discussions and activities; hence, school activities like college week should not be during school days. Proper planning of school activities should be done, cautiously ahead of time, to avoid class suspension and disruption.

New teachers bring energy and enthusiasm to their classrooms, but also a specific set of needs. Hence, school administrators should recognize that, like students, new teachers need assistance. The vice president for academic affairs and deans should seat down in an open discussion about the concerns being highlighted above. The school middle class managers to create a committee which will provide mentoring and guidance to newly hired teachers. School administrators should agree to provide extra-considerations like reducing the workload of teaching who handle subjects in writing and speech and oral communication and the like. College deans should bargain to the administration the trimming down of the English teachers' class size, or suggest uniform class size of the faculty to be fair to others. These positive moves will definitely make the newly hired teachers' work easy and fulfilling, and in turn, they could effectively perform their tasks.

Lastly, although this study was on a small-scale basis, the findings might provide a condensation of the content areas of professional development programs that need to be organized in the future. In this study particularly, the teachers see the necessity of having enough instructional materials; hence, it is suggested that the university should conduct seminar-workshops on module and textbook-making among English teachers. The outputs of the said workshop would serve as their instructional materials after it will pass the university Review Committee. Moreover, as to what other related studies need to be explored, the author believes that since the current study presents only the newly hired teachers' perspectives on the challenges that affect their teaching strategies; it may be worthwhile to take the other side of the coin i.e. learners' experiences and views on the teaching strategies used by the novice English teachers.

\section{REFERENCES}

[1] Bozack, A. R. (2008). Growing new teachers: The relationship among professional development, efficacy beliefs, and classroom practices. Retrieved from http://arizona.open- 
repository.com/arizona/bitstream/10150/195080/1/azu_etd_ sipl_m.pdf

[2] Collantes, N. E., (2014). Outcomes-Based Education. February 12, 2014 [2] Davis, M. H. (2003). OutcomeBased Education, Educational Strategies, International Journal of Educational Development. (2009). p1-6. Retrieved from http://www.utpjournals.com

[3] Creswell, J.W. (2003). Research design: Qualitative, quantitative and mixed methods approach ( $2^{\text {nd }}$ ed.) London, England: Sage.

[4] Dhanasobhon, S. (2006).English language teaching dilemma in Thailand. Retrieved January, 2013, m http://www.curriculumandinstruction.org/index.php?lay=sh ow $\&$ ac $=$ article $\& I d=539134523 \&$ Ntype $=7$

[5] Feiman-Nemser, S. (2003). What new teachers need to learn. Educational Leadership, 60 (8), 25-29.

[6] Flores, M. A., \& Day, C. (2006). Contexts which shape and reshape new teachers' identities: A multi-perspective study. Teaching and Teacher Education, 22, 219-232.

[7] Fry, S. W. (2007). First-year teachers and induction support: Ups, downs, and in-betweens. The Qualitative Report, 12(2), 216-237.

[8] Goodwill, B. (2012). Research Says / New Teachers Face Three Common Challenges. Supporting beginning $\begin{array}{llll}\text { teachers. } & \text { ASCD.Vol. } 69 . & \text { Pp. } & \text { 84-85. }\end{array}$ http://www.ascd.org/publications/educationalleadership/may12/vol69/num08/New-Teachers-FaceThree-Common-Challenges.aspx

[9] He, Y., \& Cooper, J. (2001). Struggles and strategies in teaching: Voices of five novice secondary teachers. Teacher Education Quarterly. Retrieved from http://web.ebscohost.com/ehost/pdf/pdfreviewer?vid=4\&si $\mathrm{d}=29269770$-e459-4c9f-91acc68c)bd218cf\%sessionmgr15.

[10] Hover, S. D., \& Yeager, E. A. (2004). Challenges facing beginning history teachers: An exploratory study. International Journal of Social Education, 19(1), 826.

[11] Ingersoll, R. M., \& Smith, T. M. (2003). The wrong solution to the teacher shortage. Educational Leadership, 60(8), 30-33.

[12] Mathews, J. (2011, December 18). New teacher decries lesson plan gap [blog post]. Retrieved from Class Struggle at The Washington Post at www.washingtonpost.com/blogs/classstruggle/post/new-teacher-decries-lesson-plangap/2011/12/17/gIQAt0C50O_blog.html

[13] McCormack, A., Gore, J., \& Thomas, K. (2006).Early career teacher professional learning. Asia-Pacific Journal of Teacher Education, 34(1), 95-113.

[14] Mckenzie, M.L. (2005). Stories of buoyancy and despondency: Five beginning teachers' experiences in their first year in the teaching profession (Unpublished doctoral dissertation). Australian Catholic University.

[15] Melnick, S., \& Meister, D. (2008).A comparison of beginning and experienced teachers' concerns. Educational Research Quarterly, 31(3), 39-56.
[16] Onafowora, L. L. (2004). Teacher efficacy issues in the practice of novice teachers. Educational Research Quarterly, 28, 34-43.

[17] Patton, M. Q. (2002). Qualitative research and evaluation methods. Thousand Oaks, CA: Sage. [Google Scholar]; Stake, 2005Stake, R. E. (2005). Qualitative case studies. In N. K. Denzin \& Y. S.Lincoln (Eds.), The Sage handbook of qualitative research (pp. 443-466). Thousand Oaks, CA: Sage.

[18] Putnam, R. T., \& Borko, H. (2000). What do new views of knowledge and thinking have to say about research on teacher learning? Educational Researcher, 29, 4-15.

[19] Rivkin, S. G., Hanushek, E. A., \&Kain, J. F. (2005). Teachers, schools, and academic achievement. Econometrica, 73(2), 417-458.

[20] Sewell, Alison. Exploring the development of a community of learners in four primary classrooms [online]. New Zealand Journal of Educational Studies, Vol. 46, No. 2, 2011:

[61]-74.

Availability: $\leq$ https://search.informit.com.au/documentSum mary;dn=956518874497922;res=IELNZC >ISSN: 00288276. [cited 12 Apr 19].

[21] Smith, T. M., \& Ingersoll, R. M. (2004). What are the effects of induction and mentoring on beginning teacher turnover? American Educational Research Journal, 41(3), 681-714.

[22] Whitehead, T. L. (2005). Basic classical ethnographic research methods. Ethnographically Informed community and cultural assessment research systems (Working Paper Series). College Park, MD: Cultural Ecology of Health and Change.

[23] Windschitl, M. Thompson, J, Stroupe, M.B.D Chew, C. \& Wright, B. (2010). The beginner's repertoire: A core set of instructional practices for teacher preparation. Paper presented at the annual meeting of the American Educational Research Associations, Denver, CO.

[24] Vygotsky, L. S. (1978). Mind in society: The development of higher psychological processes. Cambridge, MA: Harvard University Press. 